\title{
Rapid detection of single nucleotide mutation in p53 gene based on gold nanoparticles decorated on graphene nanosheets
}

\author{
SEYEDEH ZEINAB MOUSAVISANI, JAHAN BAKHSH RAOOF*, REZA OJANI \\ and ROUDABEH VALIOLLAHI \\ Electroanalytical Chemistry Research Laboratory, Department of Analytical Chemistry, \\ Faculty of Chemistry, University of Mazandaran, Babolsar, Iran \\ e-mail: j.raoof@umz.ac.ir
}

MS received 14 June 2016; revised 24 August 2016; accepted 12 October 2016

\begin{abstract}
A simple and highly sensitive electrochemical DNA sensor for the rapid detection of a specific DNA sequence related to the $\mathrm{p} 53$ gene is described. The structure and morphology of the synthesized graphene nanosheets and Au nanoparticles were characterized through transmission electron microscopy, UV-Vis spectroscopy and energy dispersion X-ray spectroscopy techniques. The new electrochemical biosensor was prepared by modifying a graphite screen printed electrode (SPE) with gold nanoparticles decorated on graphene (AuNPs/G) nanocomposite. Cyclic voltammetry (CV) and electrochemical impedance spectroscopy (EIS) techniques were employed to clarify the changes in charge transfer during the fabrication and utilization of the DNA biosensor. The DNA hybridization event was monitored by differential pulse voltammetry (DPV). Under optimal conditions, the decrease of the peak current had a linear relation with the logarithm of the concentration of target complementary DNA in the range $0.5 \mathrm{fM}$ to $0.05 \mathrm{nM}$, with a detection limit of $0.36 \pm 0.04 \mathrm{fM}$.
\end{abstract}

Keywords. Graphite; screen printed electrode; Graphene nanosheets; Gold nanoparticles; DNA hybridization.

\section{Introduction}

Considerable attention has been paid to sequencespecific detection of DNA targets in various fields such as: genetic mutations, monitoring of infectious agents, clinical medicines and forensic investigation. ${ }^{1}$ Up until now, various sensing strategies such as surface plasmon resonance spectroscopy, ${ }^{2}$ quartz crystal microbalance, ${ }^{3}$ fluorescence, ${ }^{4}$ surface-enhanced Raman scattering ${ }^{5}$ and electrochemical methods ${ }^{6}$ have been adopted for DNA detection. Among the mentioned methods, electrochemical methods have gained substantial attention compared to other methods, due to their highsensitivity, simplicity, fast-response, low-cost, and compatibility with micro fabrication technologies. ${ }^{7}$ Electrochemical detection methods for DNA hybridization are divided into two categories: indirect ${ }^{8,9}$ and direct. ${ }^{10}$ DNA electrochemical biosensors are based on monitoring signal variations following hybridization reaction between single-stranded DNA (ssDNA) and its complementary strand. ${ }^{11}$

Recently, nanomaterials due to their unique properties (e.g., excellent catalytic/electronic/mechanical properties, large surface-to-volume ratio, etc.), have

*For correspondence been widely used in the design of biosensing systems with advanced performance for the purpose of achieving more selective and sensitive electrochemical DNA biosensors. ${ }^{12,13}$

Graphene, a new class of two-dimensional sheet material, which was discovered by Geim et al., in $2004,{ }^{14}$ has obtained extensive scientific and industrial interest because of its unique properties. ${ }^{15}$ It has been found to have potential applications in many technological aspects, such as: sensing, ${ }^{16,17}$ capacitors, ${ }^{18}$ solar cells, ${ }^{19}$ cell imaging ${ }^{20}$ and drug delivery systems. ${ }^{21}$ Graphene with fascinating physical and chemical properties, such as large surface area, good chemical stability, excellent electrical conductivity and strong mechanical strength ${ }^{22}$ attracted intense research interest in the field of DNA biosensors. Moreover, graphene sheets decorated with nanoparticles have recently gained increasing attention due to their capability of preventing nanoparticle aggregation. ${ }^{23}$ In some cases, the electron transfer between the analyte and the electrode is facilitated by decorating graphene with nanoparticles. ${ }^{24} \mathrm{Up}$ until now, numerous reports have been published based on their applications. For instance, Yola et al., constructed a novel and sensitive electrochemical biosensor based on Fe@Au nanoparticles (Fe@AuNPs) involving graphene oxide (GO) 
which is functionalized with 2-aminoethanethiol (AET) (Fe@AuNPs-AETGO for selective determination of DNA). ${ }^{25}$ Liu et al., prepared a label-free electrochemical DNA biosensor for rapid detection of multidrug resistant gene based on Au nanoparticles/toluidinebluegraphene oxide nanocomposites. ${ }^{26}$

P53 gene codes the protein which regulates the cell cycle and it also acts as a tumor suppressor. It has been depicted as "the guardian of the genome" because of its function in preserving stability by preventing genome mutation. ${ }^{27}$ Nevertheless, more than $50 \%$ of all human tumors contain p53 mutation; hence, efforts to achieve sensitive and rapid detection of the P53 gene sequence and its mutations is of prime importance. Up to now, numerous reports have been devoted to p53 DNA mutation detection. Our research group previously fabricated an electrochemical biosensor based on a peptide nucleic acid (PNA) probe for the detection of single nucleotide mutation (SNM) in the p53 tumor suppressor gene. ${ }^{28}$ Besides, we introduced $\mathrm{Au} / \mathrm{Pt}$ bimetallic nanocomposite electrode as a new biosensor for direct detection of p53 DNA plasmid. ${ }^{29}$ The high importance of the p53 gene mutation detection in various fields of biology and medicine persuaded us to find out a new procedure for the rapid detection of the target DNA sequence and single nucleotide mutation in the p53 gene and corresponding oligonucleotide by using of the graphene substrate. In this research, for the first time we use graphene nanocomposite as substrate to do DNA hybridization by applying positive potential procedure.

\section{Experimental}

\subsection{Chemicals}

The probe DNA (ssDNA) corresponding to the short sequence of p53, g53g gene, its complementary DNA (cDNA), single base mismatched (SBM), and two noncomplementary (ncDNA) were synthesized by MWGBiotech company, Germany. Their base sequences are listed below:

ssDNA: 5' -TGG GGA TGG AGA ACT- 3'

cDNA: $5^{\prime}$-AGT TCT CCA TCC CCA- $3^{\prime}$

SBM DNA: 5' -AGT TCT GCA TCC CCA- $3^{\prime}$

nc1DNA: $5^{\prime}$-CTA AAT TTA GCA CTT CCT CC- $3^{\prime}$ nc2DNA: 5' -GTT ACT GTG GTA GAT ACT AC- 3'

All oligonucleotide stock solutions $(100 \mu \mathrm{M})$ were prepared using $10.0 \mathrm{mM}$ Tris- $\mathrm{HCl}, 1.0 \mathrm{mM}$ EDTA solution ( $\mathrm{pH}$ 8.00) and stored in a freezer. More dilute solutions were obtained by using $0.50 \mathrm{M}$ acetate buffer solution ( $\mathrm{pH} 4.80$ ) containing $20.0 \mathrm{mM} \mathrm{NaCl}$. Tetrachloroauric (III) acid trihydrate $\left(\mathrm{HAuCl}_{4} \cdot 3 \mathrm{H}_{2} \mathrm{O}\right)$, sulfuric acid, graphite powder, sodium borohydride and sodium nitrate were purchased from Merck, Germany. Sodium hydroxide was purchased from Fluka, Switzerland. Other chemicals were analytical reagent grade and purchased from Fluka, Switzerland. Distilled, deionized and sterilized water was used in all solution preparation. All the experiments were carried out at room temperature.

\subsection{Instrumentation}

All electrochemical measurements were performed using Metrohm Autolab PG30 electrochemical analysis system controlled by GPES 4.9 and FRA software (Eco Chemie, Netherlands). The graphite screen-printed electrodes (SPEs, Florence, Italy) were composed of a carbon working electrode, a carbon counter-electrode and a silver pseudo-reference electrode.

The materials and procedures for screen printing as transducers have been defined elsewhere. ${ }^{30}$ The morphologies of the synthesized graphene nanosheets and AuNPs, were investigated with transmission electron microscopy (TEM) using a PHILIPS CM30, Netherlands. Elemental mapping images were obtained by energy-dispersive X-ray analysis (EDX) using VEGATESCAN-XMU electron microscope, USA. UV-Vis absorption spectrum was recorded using a UV-Vis instrument (Cambridge, UK) and FT-IR spectrum was obtained by using a Bruker Tensor 27, Germany.

\subsection{Procedure}

2.3a Synthesis of Graphene and AuNPs: Graphene oxide (GO) was prepared from graphite powder based on the modified Hummers method. ${ }^{31}$ In brief, $5 \mathrm{~g}$ graphite powder, $2.5 \mathrm{~g} \mathrm{NaNO}_{3}$ and $120 \mathrm{~mL}$ of $\mathrm{H}_{2} \mathrm{SO}_{4}$ $(95 \%)$ were mixed under stirring in an ice bath. 30 minutes later, $\mathrm{KMnO}_{4}(15 \mathrm{~g})$ was gradually added under stirring in the ice-bath and afterwards, the resulting mixture was further stirred at room temperature overnight. Subsequently, $150 \mathrm{~mL}$ of $\mathrm{H}_{2} \mathrm{O}$ was gently added to the pasty mixture under intense stirring, which led to a quick raise in the reaction temperature to $98^{\circ} \mathrm{C}$ with effervescence. The resulting suspension was stirred at $98^{\circ} \mathrm{C}$ in an oil bath with reflux for 1 day. After $24 \mathrm{~h}, 50 \mathrm{~mL}$ of $30 \% \mathrm{H}_{2} \mathrm{O}_{2}$ was added to the mixture. Next, the mixture was washed by adding $5 \% \mathrm{HCl}$ and then with deionized (DI) water and centrifugation for several times until it achieved a neutral $\mathrm{pH}$. Ultimately, the product, i.e., GO was acquired after filtration and drying. Graphene was easily prepared by reducing GO via a chemical route by using hydrazine as a reducing agent. Typically, $50 \mathrm{mg}$ of GO was dispersed in $20 \mathrm{~mL}$ 
DI water by ultrasonication for $1 \mathrm{~h}$. Afterwards, $0.5 \mathrm{~mL}$ of hydrazine monohydrate was added and the mixture was stirred at $90^{\circ} \mathrm{C}$ in an oil bath with reflux for $24 \mathrm{~h}$. Finally, in order to remove the excessive hydrazine, the mixture was washed with DI water and centrifuged several times. The final product was dried and thus graphene was obtained in the form of a black powder.

$\mathrm{Au}$ nanoparticles were synthesized by the citrate reduction method as reported in the literature. ${ }^{32}$ Typically, $50 \mathrm{~mL}$ solution containing $0.01 \% \mathrm{HAuCl}_{4} \cdot 3 \mathrm{H}_{2} \mathrm{O}$ and $1 \%$ sodium citrate was prepared and heated with stirring until it started boiling. Then, while it was still boiling, $2.5 \mathrm{~mL}$ of sodium citrate $(1 \%)$ was added. At this step, the solution color changed to dark red. Then, the solution was kept at the same temperature with stirring for $10 \mathrm{~min}$, which was followed by an additional $10 \mathrm{~min}$ of stirring at room temperature. In order to immobilize the as-prepared gold nanoparticles on graphene support, $10 \mathrm{mg}$ of prepared graphene was added to the Au nanoparticles solution and stirred for $24 \mathrm{~h}$. Finally, the obtained product (AuNPs/G) was centrifuged and collected as a black solid product and washed with distilled water and dried in an oven $\left(70^{\circ} \mathrm{C}\right)$ and at the end collected as dried powder.

2.3b The principle of the biosensor protocol: First, AuNPs/G was dispersed in water with ultrasonication for $25 \mathrm{~min}$ in order to achieve a homogenous suspension $\left(1 \mathrm{mg} \mathrm{mL}^{-1}\right)$. Then, a droplet of $8 \mu \mathrm{L}$ AuNPs/G was coated on the working electrode surface and naturally dried in the air for $1 \mathrm{~h}$, which led to SPE modified with AuNPs/G (AuNPs/G/SPE). Next, AuNPs/G/SPE was dipped in $0.50 \mathrm{M}$ acetate buffer solution $(\mathrm{pH}$ 4.8) containing $1.0 \mu \mathrm{M}$ ssDNA and $20 \mathrm{mM}$ of $\mathrm{NaCl}$, while the potential of $0.5 \mathrm{~V}$ (optimum potential) was applied for the optimum time of 5 min under stirring condition at room temperature. Afterwards, the prepared ssDNA/AuNPs/G/SPE was washed with ultrapure water to remove the unbound DNA which was then used for the hybridization step as a probe DNA. The fabrication protocol of the biosensor is depicted in Scheme 1. 2.3c DNA hybridization: The DNA hybridization reaction was accomplished based on the work of Pournaghi-Azar et al. ${ }^{33,34}$ It was based on immersing the probe captured platform into a stirred target DNA solution ( $0.5 \mathrm{M}$ acetate buffer, $\mathrm{pH} 4.8)$ containing $1.0 \mu \mathrm{M}$ of complementary target DNA and $20 \mathrm{mM}$ of $\mathrm{NaCl}$ whereas, $0.5 \mathrm{~V}$ potential was applied to the electrode for 5 min (optimum condition). Finally, the electrode was rinsed with ultrapure water to remove the unhybridized DNA. The same procedure was repeated using the SBM and ncDNA sequences instead of the complementary target DNA sequence to compare the hybridization event in the presence of mismatch complementary DNA.

2.3d Electrochemical measurements: The cyclic voltammetry $(\mathrm{CV})$ technique was carried out in $0.1 \mathrm{M}$ $\mathrm{KCl}$ solution containing $5.0 \mathrm{mM}\left[\mathrm{Fe}(\mathrm{CN})_{6}\right]^{3-/ 4-}$ in the potential range of -0.6 to $+0.8 \mathrm{~V}$ with a potential scan rate of $100 \mathrm{mV} \mathrm{s}^{-1}$. The impedance spectroscopy (EIS) measurement was conducted in the same supporting electrolyte that was used in $\mathrm{CV}$, by applying the $\mathrm{AC}$ voltage amplitude of $5 \mathrm{mV}$, and the frequency range of $10 \mathrm{KHz}-0.1 \mathrm{~Hz}$ at the open circuit potential. The DPV signals were obtained in $0.1 \mathrm{M}$ PBS ( $\mathrm{pH} 7.0$ ) containing $5.0 \mathrm{mM}\left[\mathrm{Fe}(\mathrm{CN})_{6}\right]^{3-}$ and $0.1 \mathrm{M} \mathrm{KCl}$ using the potential scan rate of $20 \mathrm{mV} \mathrm{s}^{-1}$. The raw data were then treated using the Savitzky and Golay filter (level 2) of GPES software, followed by the GPES software moving average baseline correction using a "peak width" of 0.02 .

\section{Results and Discussion}

\subsection{Characterization of graphene and $\mathrm{Au}$ nanoparticles}

The FT-IR spectra of GO and graphene $(\mathrm{G})$ are presented in Figure 1. As can be seen, the characteristic bands of GO were observed at 3427, 1723, and $1058 \mathrm{~cm}^{-1}$ which can be assigned to the stretching

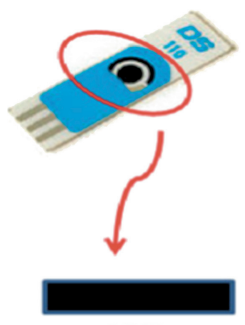

SPE
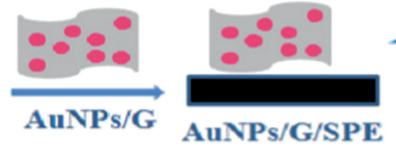

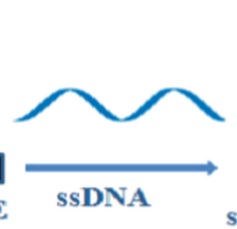

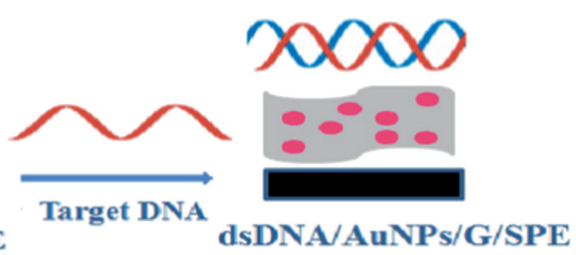

Scheme 1. Schematic illustration of the fabrication steps of the biosensor. 


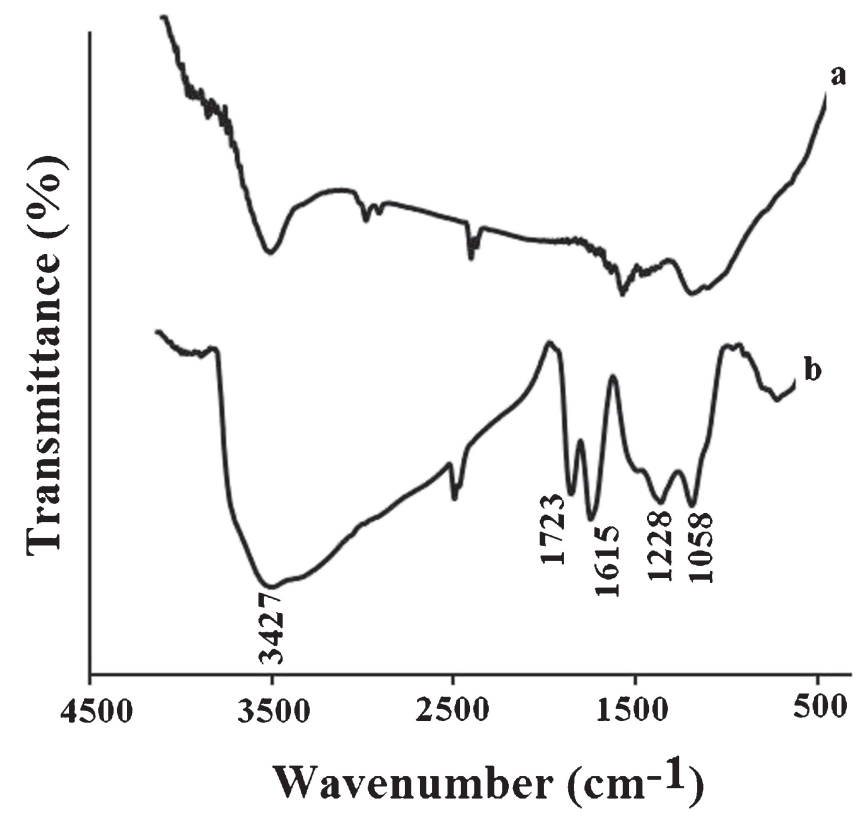

Figure 1. FT-IR spectra of (a) graphene and (b) graphene oxide.

vibration of $\mathrm{O}-\mathrm{H}, \mathrm{C}=\mathrm{O}$, and $\mathrm{C}-\mathrm{O}-\mathrm{C}$, respectively. The bands at 1615 and $1228 \mathrm{~cm}^{-1}$ are attributed to the vibration of carboxyl groups. ${ }^{35,36}$ After chemical reduction of GO, the peak intensities decreased significantly. This result confirms that the number of hydroxyl, epoxy, and carboxyl functional groups of GO is diminished.

The morphologies of the synthesized graphene nanosheets and Au nanoparticles were investigated by TEM. Graphene sheets are rippled like a silk weave due to their extremely small thickness and flexible structures (Figure 2A). It can also be found from Figure 2B that the prepared Au nanoparticles have spherical shape with the average size of $16 \mathrm{~nm}$.

The EDX analysis of the AuNPs/G (Figure 3A) clearly shows the bands related to $\mathrm{C}$ and $\mathrm{Au}$, implying the successful deposition of gold nanoparticles on graphene sheets. The Au mass percentage of AuNPs/G is 6.23 .

According to the UV-Visible absorption spectrum (Figure 3B), the prepared Au nanoparticles have $\lambda_{\max }=$ $523 \mathrm{~nm}$ which confirms that the particle size is about $20 \mathrm{~nm} .{ }^{37}$ Therefore, the estimations of the particles size by TEM and UV-Visible absorption spectrum are in good agreement.

\subsection{EIS analysis of the DNA biosensor}

EIS, which is a sensitive and efficient tool, has been utilized in electrochemical biosensors to monitor the alteration of electrode interface based on biological and chemical molecule recognition. ${ }^{38}$ The Nyquist diagram

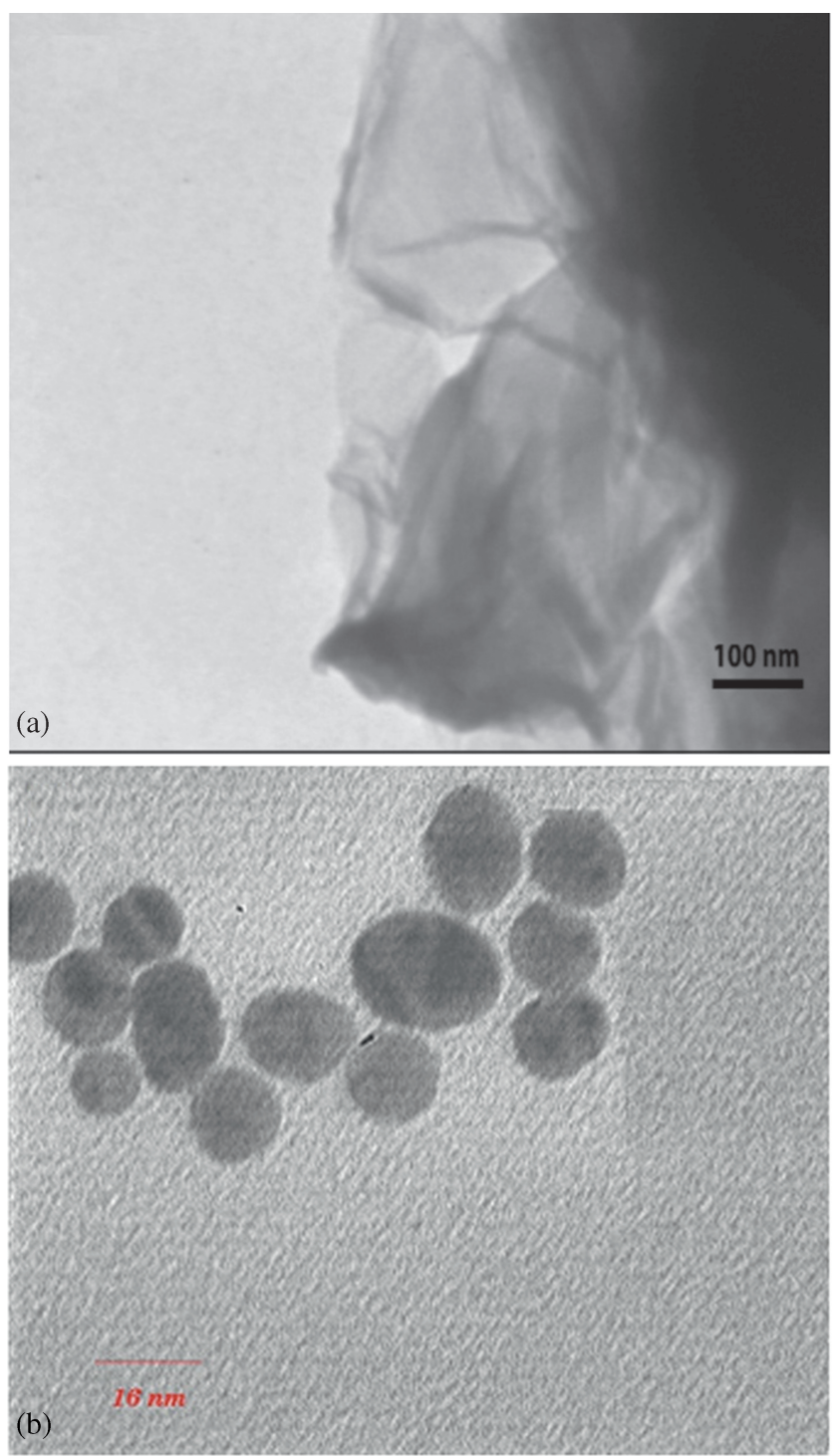

Figure 2. TEM images of prepared graphene nanosheets (A) and gold nanoparticles (B).

consists of a semicircle portion at higher frequencies and a linear part at low frequencies, which relate to the electron transfer process and diffusion process, respectively. The electron transfer resistance, $R_{\mathrm{ct}}$, can be directly evaluated as the semicircle diameter of the Nyquist diagram. ${ }^{39}$ Figure $4 \mathrm{~A}$ shows the representative Nyquist plots of the bare SPE (a), G/SPE (b), AuNPs/G/SPE (c), ssDNA/AuNPs/G/SPE (d) and dsDNA/AuNPs/G/SPE (e) in $0.1 \mathrm{M} \mathrm{KCl}$ solution including $5.0 \mathrm{mM}\left[\mathrm{Fe}(\mathrm{CN})_{6}\right]^{3-/ 4-}$. The plot for the curves (b) to (d) have been displayed in Figure 4B. The data can be fitted with the equivalent circuit (Figure $4 C$ ) where $R_{s}$ is the solution resistance, $R_{c t}$ is the charge transfer resistance, $\mathrm{W}$ is the Warburg impedance and CPE is the constant phase element. It could be seen that after the coating of graphene nanosheets on SPE, the $\mathrm{R}_{\mathrm{ct}}$ clearly decreased from 
$14.43 \mathrm{k} \Omega$ at bare SPE (curve a) to $2.602 \mathrm{k} \Omega$ (curve b), indicating that graphene nanosheets accelerated the electron transfer between $\left[\mathrm{Fe}(\mathrm{CN})_{6}\right]^{3-/ 4-}$ redox couple and the electrode surface. The major reason for

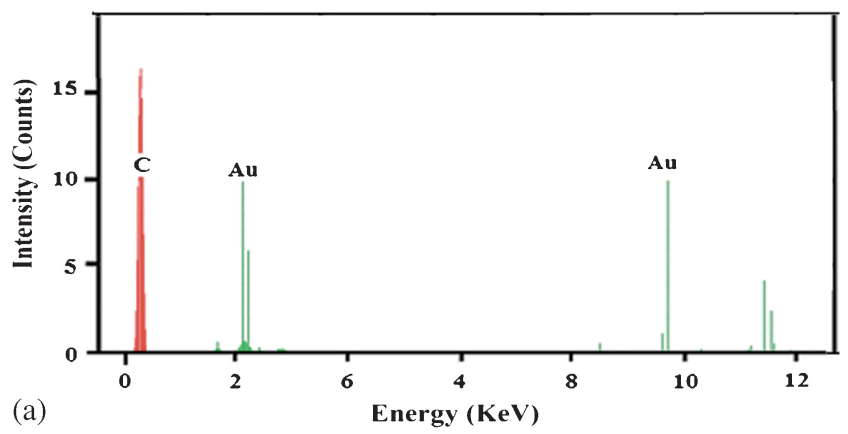

(a)

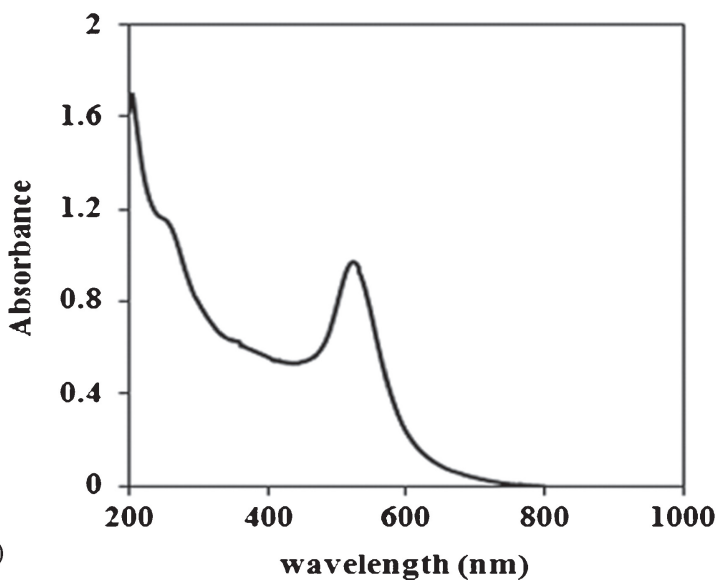

Figure 3. (A) EDX spectrum of AuNPs/G. (B) UV-Vis absorption spectrum of gold nanoparticle solution at $\sim 0.2 \mathrm{mM}$, and the path length was $1 \mathrm{~cm}$.

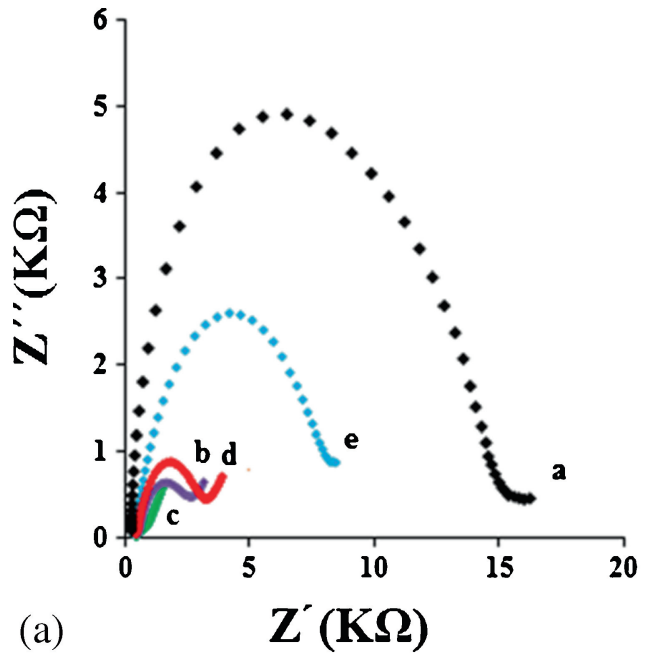

Figure 4. (A) Nyquist plots at SPE (a), G/SPE (b), AuNPs/G/SPE (c), ssDNA/AuNPs/G/SPE (d) and dsDNA/AuNPs/G/SPE (e) in $0.1 \mathrm{M} \mathrm{KCl} \mathrm{containing}$ $5.0 \mathrm{mM}\left[\mathrm{Fe}(\mathrm{CN})_{6}\right]^{3-/ 4-}$. (B) Expanded view. (C) Equivalent circuit. this observation was ascribed to remarkable improvement of electrical conductivity at the G/SPE surface due to the presence of graphene nanosheets. ${ }^{40}$ The value of $R_{c t}$ at the AuNPs/G/SPE surface decreased greatly to $0.416 \mathrm{k} \Omega$ (curve c), which indicates better electrical conductivity at this surface due to the presence of $\mathrm{Au}$ nanoparticles. Subsequently, the $\mathrm{R}_{\mathrm{ct}}$ increased distinctively to $2.806 \mathrm{k} \Omega$ (curve d) after immobilization of probe DNA on the AuNPs/G/SPE surface, that is related to the electrostatic repulsion between the same charges of $\left[\mathrm{Fe}(\mathrm{CN})_{6}\right]^{3-/ 4-}$ and probe DNA. Besides, DNA itself could be defined as an insulator or a semiconductor. ${ }^{41}$ When target complementary DNA is hybridized with the probe DNA, the resulting dsDNA with more negative charge implies a high electron transfer resistance and enlarges the diameter of the semicircle in the impedance spectrum; $R_{c t}=8.081 \mathrm{k} \Omega$ (curve e). This significant increase in $R_{c t}$ value from 2.806 to $8.081 \mathrm{k} \Omega$ after DNA hybridization is proof that dsDNA was successfully formed on the AuNPs/G/SPE.

\subsection{Electrochemical characterization of the modified electrodes}

Cyclic voltammetry is an efficient and suitable method for investigating the features of modified electrode surfaces. ${ }^{26}$ The cyclic voltammograms of $\left[\mathrm{Fe}(\mathrm{CN})_{6}\right]^{3-/ 4-}$ redox couple at the electrode surface modification steps are exhibited in Figure 5A. The bare SPE displays a pair of apparent redox peaks, with cathodic $\left(\mathrm{I}_{\mathrm{pc}}\right)$ and anodic $\left(\mathrm{I}_{\mathrm{pa}}\right)$ peak currents of

(c)
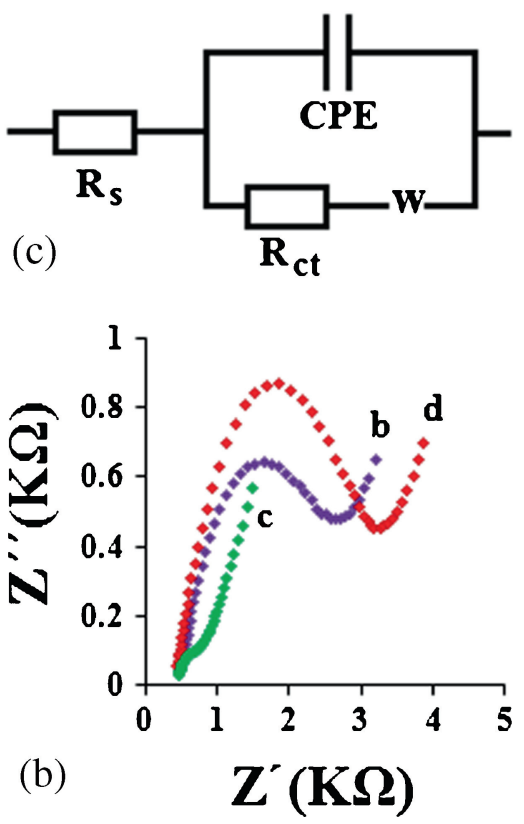

(b) 
$-36.01 \mu \mathrm{A}$ and $42.27 \mu \mathrm{A}$, respectively, and the peakto-peak potential separation $\left(\Delta \mathrm{E}_{\mathrm{p}}=\mathrm{E}_{\mathrm{pa}}-\mathrm{E}_{\mathrm{pc}}\right)$ of $0.664 \mathrm{~V}$ (curve a). When graphene nanosheets were deposited on the surface of SPE, the peak currents changed to the new values as: $\mathrm{I}_{\mathrm{pc}}=-65.48 \mu \mathrm{A}$ and $\mathrm{I}_{\mathrm{pa}}=79.93 \mu \mathrm{A}$ and $\Delta \mathrm{E}_{\mathrm{p}}$ changed to $0.47 \mathrm{~V}$ (curve $\mathrm{b}$ ), indicating an increase of specific surface area and the rate of electron transfer at G/SPE. After the coating of AuNPs/G on SPE, the signal intensity increased significantly $\left(\mathrm{I}_{\mathrm{pc}}=-84.36 \mu \mathrm{A}, \mathrm{I}_{\mathrm{pa}}=88.31 \mu \mathrm{A}\right)$ with $\Delta \mathrm{E}_{\mathrm{p}}$ of 0.18 (curve $\mathrm{c}$ ). This could be attributed to the integration of individual benefits of graphene nanosheets and AuNPs (such as large surface area, high electronic
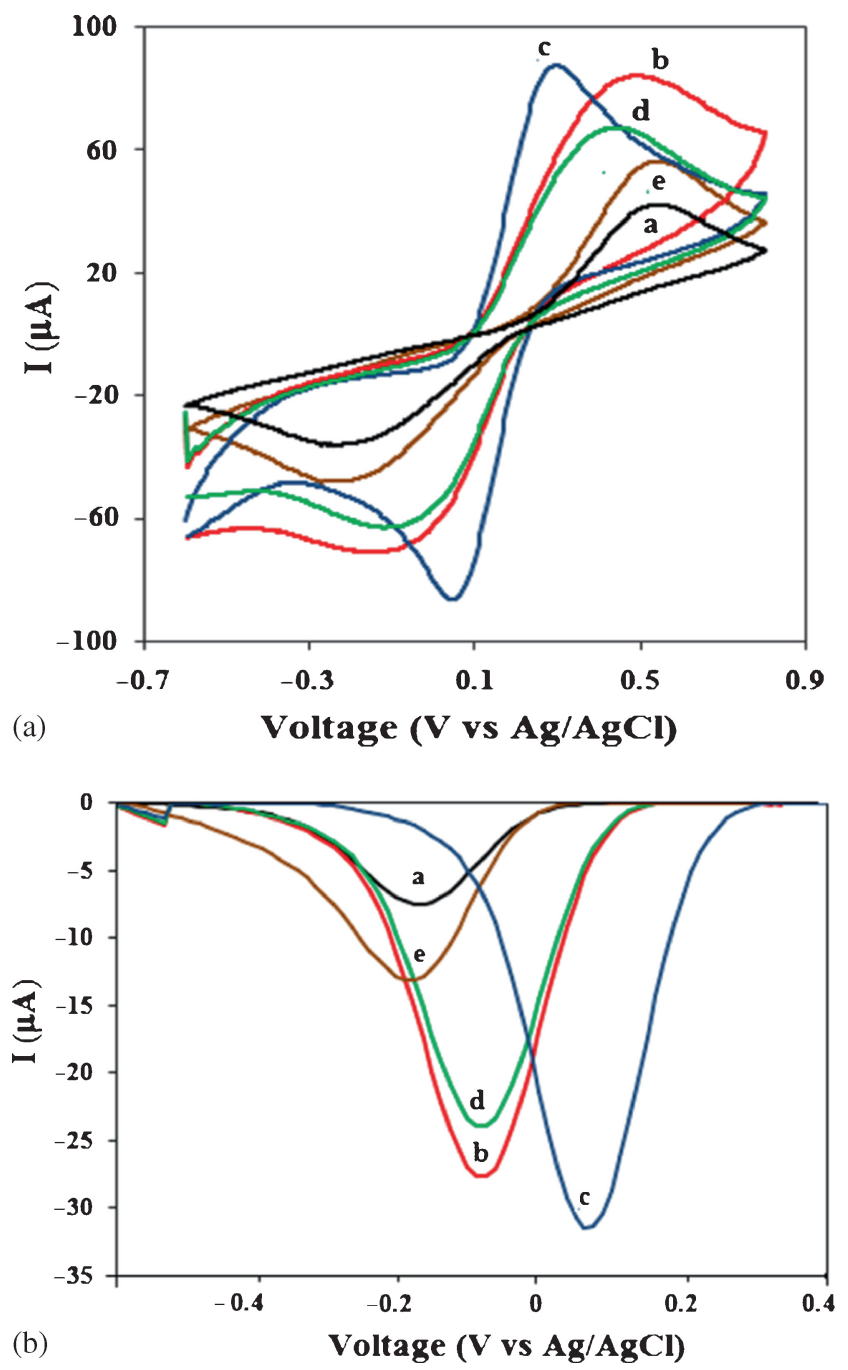

Figure 5. (A) CV curves for different modified electrodes: (a) SPE, (b) G/SPE, (c) AuNPs/G/SPE, (d) ssDNA/AuNPs/G/SPE and (e) dsDNA/AuNPs/G/SPE in $0.1 \mathrm{M} \mathrm{KCl}$ containing $5.0 \mathrm{mM}\left[\mathrm{Fe}(\mathrm{CN})_{6}\right]^{3-/ 4-}$ solution at a scan rate of $100 \mathrm{mV} \mathrm{s}^{-1}$. (B) DPV signal for various electrodes: (a) SPE, (b) G/SPE, (c) AuNPs/G/SPE, (d) ssDNA/AuNPs/G/SPE and (e) dsDNA/AuNPs/G/SPE in $0.1 \mathrm{M}$ PBS ( $\mathrm{pH} 7.0$ ) containing $5.0 \mathrm{mM}\left[\mathrm{Fe}(\mathrm{CN})_{6}\right]^{3-}$ and $0.1 \mathrm{M} \mathrm{KCl}$. conductivity and excellent catalytic property), which exhibited synergistic effects for the electrochemical response of $\left[\mathrm{Fe}(\mathrm{CN})_{6}\right]^{3-/ 4-}$ at the AuNPs/G/SPE surface as compared to bare SPE. Following the immobilization of ssDNA on the surface of the modified electrode, the peak currents of the redox pair were decreased, and the $\Delta \mathrm{E}_{\mathrm{p}}$ was enhanced (curve d), implying that the probe DNA was successfully immobilized on the AuNPs/G/SPE surface. The main reason for this observation is the electrostatic repulsive force between the negatively charged phosphate backbone of probe DNA on the surface of electrode and negatively charged $\left[\mathrm{Fe}(\mathrm{CN})_{6}\right]^{3-/ 4-}$ in the solution. On the other hand, the steric hindrance of the DNA molecules may also decrease the electron transfer rate. When the hybridization event of the probe DNA was carried out with target complementary DNA (curve e), further decrease was observed in the peak current, which was attributed to the increment of the negative charge responsible for the repulsion between DNA and the redox couple. Moreover, DPV responses of $\left[\mathrm{Fe}(\mathrm{CN})_{6}\right]^{3-}$ for different prepared electrodes were investigated, and the results showed the same trend as for the $\mathrm{CV}$ studies (Figure 5B). Based on these results, it can be distinctly concluded that DNA immobilization and hybridization were effectively carried out using the procedure presented above.

\subsection{Optimization of the experimental conditions}

The effective experimental variables on the electrochemical performance of the proposed biosensor, such as, probe DNA immobilization potential, probe DNA immobilization time and hybridization conditions (i.e., hybridization potential and time) were optimized. Accordingly, the effect of the mentioned variables on the DPV signal of $\left[\mathrm{Fe}(\mathrm{CN})_{6}\right]^{3-}$ was investigated. As shown in Figure 6A, the signal intensity decreased by increasing the applied immobilization potential from $-0.5 \mathrm{~V}$ to $+0.5 \mathrm{~V}$ and tended to approach a stable value when the potential was further increased. Thus, the ssDNA immobilization potential was selected as $+0.5 \mathrm{~V}$. Figure $6 \mathrm{~B}$ displays the influence of ssDNA immobilization time on the response signal concerning $\left[\mathrm{Fe}(\mathrm{CN})_{6}\right]^{3-}$. As it can be observed, the amount of adsorbed DNA increased by increasing the immobilization time of ssDNA from 0 to $300 \mathrm{~s}$ and then reached a stable level. An immobilization time of $5 \mathrm{~min}$ was used in the subsequent experiments. The results of Figure 6C showed that the change in the DPV signal enhanced along with the increase of hybridization potential in the range of $-0.5 \mathrm{~V}$ to $+0.5 \mathrm{~V}$, and it started to level off after $+0.5 \mathrm{~V}$. Therefore, $+0.5 \mathrm{~V}$ was selected as 
the optimum potential for the hybridization process. As shown in Figure 6D, the peak current increased as the hybridization time increased in the range of 0-300 s, and remained constant after $300 \mathrm{~s}$, indicating that the hybridization reaction was completed at $300 \mathrm{~s}$.

\subsection{Selectivity of the DNA biosensor}

In order to investigate the selectivity of the biosensor, the DPV signals of $\left[\mathrm{Fe}(\mathrm{CN})_{6}\right]^{3-}$ on the ssDNA/AuNPs/G/SPE before and after hybridization with cDNA, SBM and two ncDNA sequences were recorded. The obtained results are shown in Figure 7. It is clearly observed that the highest peak current was obtained on ssDNA/AuNPs/G/SPE (curve a), suggesting that the prepared DNA probe has the least amount of negative charge and consequently, the least repulsion. After hybridization with the complementary target sequences, the peak current decreased dramatically (curve e), which implied that dsDNA is formed at the AuNPs/G/SPE. As the non-complementary sequences were hybridized (curves b, c), the peak current slightly changed in comparison with curve a. The slight decrement of current might be attributed to nonspecific adsorption. When hybridization was performed with the SBM sequence (curve d), the signal was lower than that of ncDNA sequences $(b, c)$ but on the other hand, it is slightly higher than that with a complementary DNA sequence (e). This behavior indicates that the hybridization has not been completely performed in the presence of single base mismatched sequence. Thus, this biosensor could provide effective discrimination against point mutation. The obtained results illustrate that only complementary target DNA sequence could result in a noticeable decrease of the peak current, meaning good selectivity to sequence-specific detection of the sensor. On the other hand, these results confirm that DNA hybridization was carried out successfully by the procedure presented in the section $2.3 \mathrm{c}$. In the following sections, the analytical performance of the proposed DNA sensor is reported.

\subsection{Analytical performance of the DNA biosensor}

The sensitivity of the biosensor was studied by measuring the DPV signal of $\left[\mathrm{Fe}(\mathrm{CN})_{6}\right]^{3-}$ after hybridization

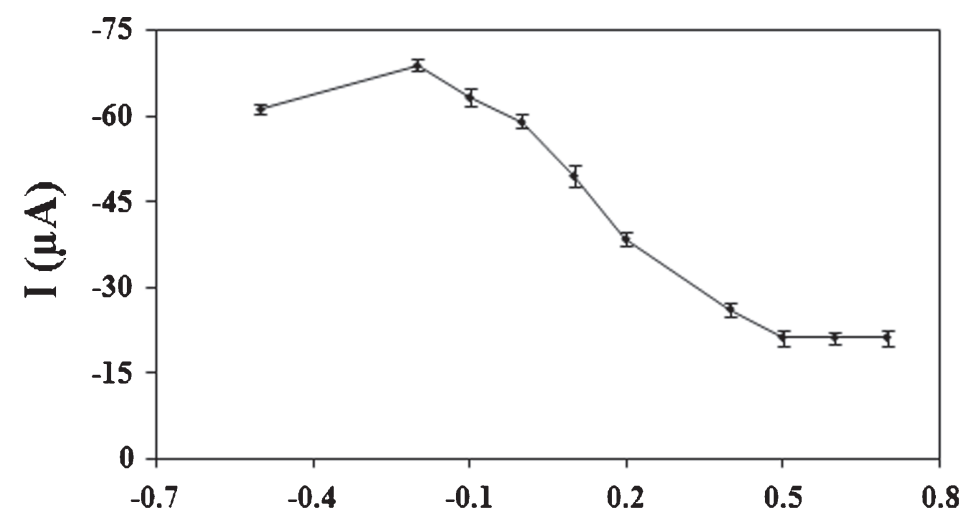

(a)

Applied immobilization potential (V)

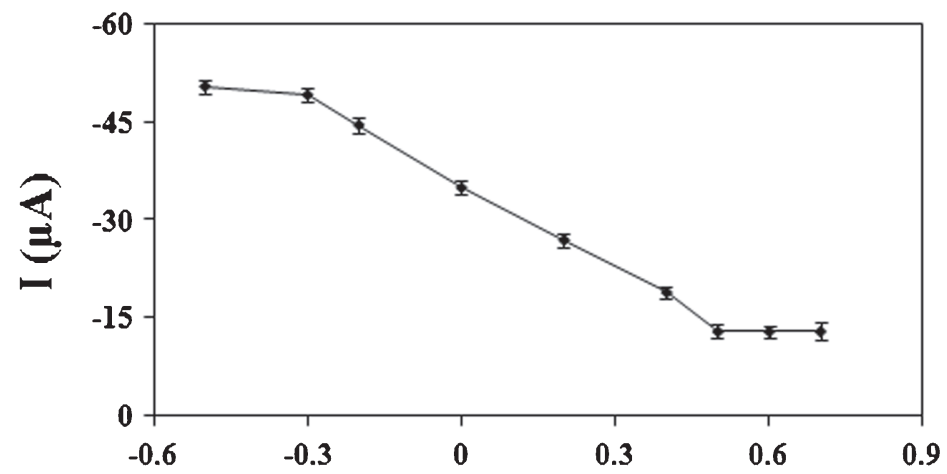

(c)

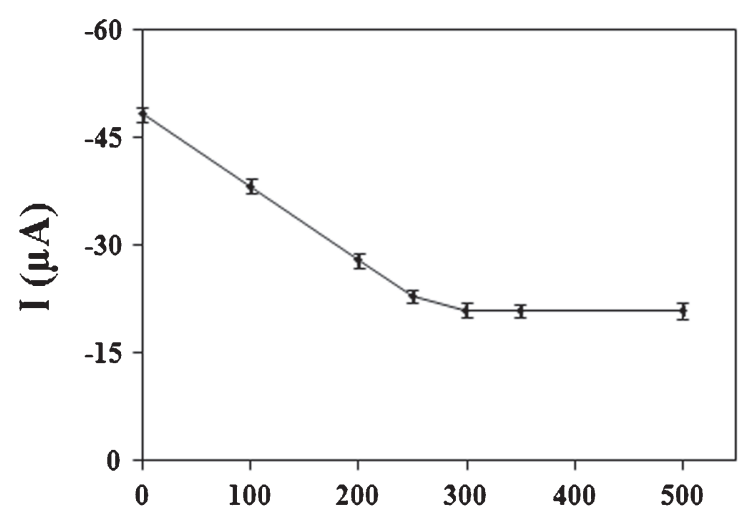

(b) ssDNA immobilization time (s)

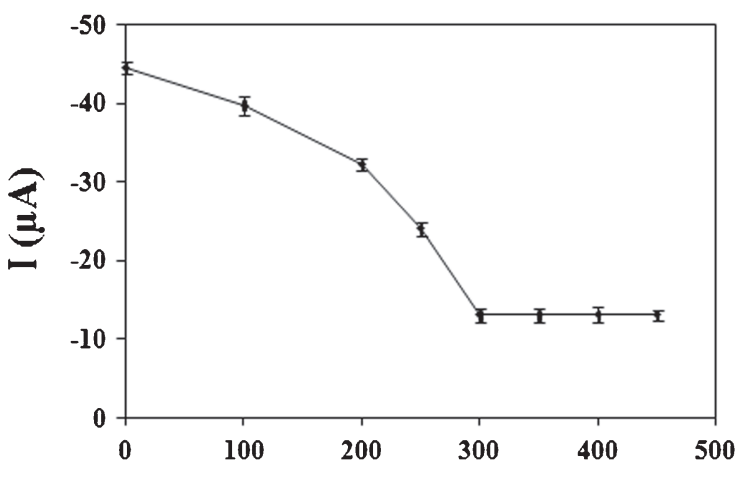

(d)
DNA hybridization time (s)

Figure 6. The effects of (A) ssDNA immobilization potential, (B) ssDNA immobilization time, (C) DNA hybridization potential and (D) hybridization time on the DPV signal of $\left[\mathrm{Fe}(\mathrm{CN})_{6}\right]^{3-}$ in $0.1 \mathrm{M} \mathrm{PBS}(\mathrm{pH} 7.0)$ and $0.1 \mathrm{M} \mathrm{KCl}$. Error bars are estimated as the standard deviation from triple measurements $(n=3)$. 


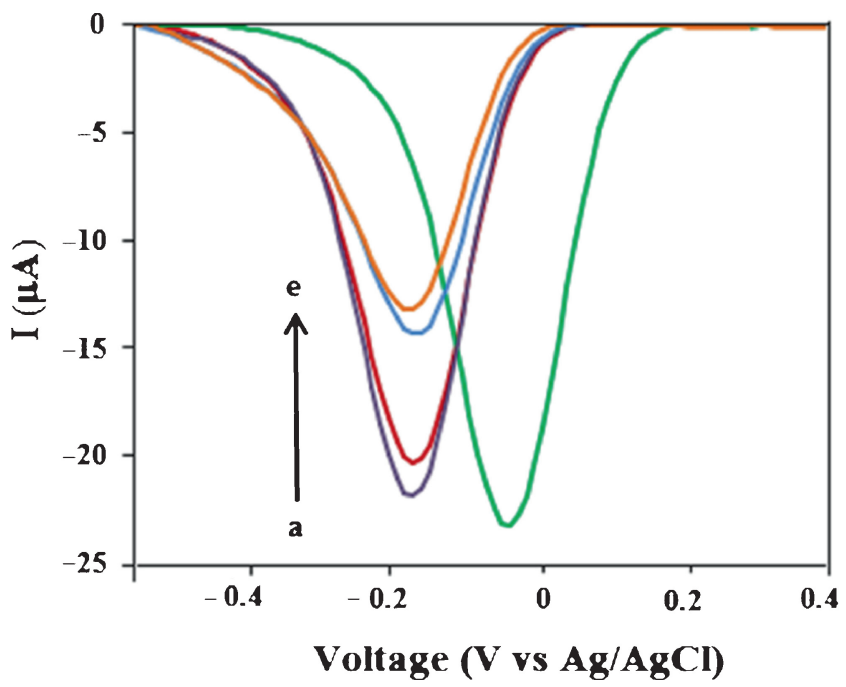

Figure 7. DPV signals of $5.0 \mathrm{mM}\left[\mathrm{Fe}(\mathrm{CN})_{6}\right]^{3-}$ in $0.1 \mathrm{M}$ PBS (pH 7.0) and $0.1 \mathrm{M} \mathrm{KCl}$ on the ssDNA/AuNPs/G/SPE (a) and its hybridization with $1.0 \mu \mathrm{M}$ different target sequences: complementary sequence (e), nc1 (b), nc2 (c) and $\operatorname{SBM}(d)$.

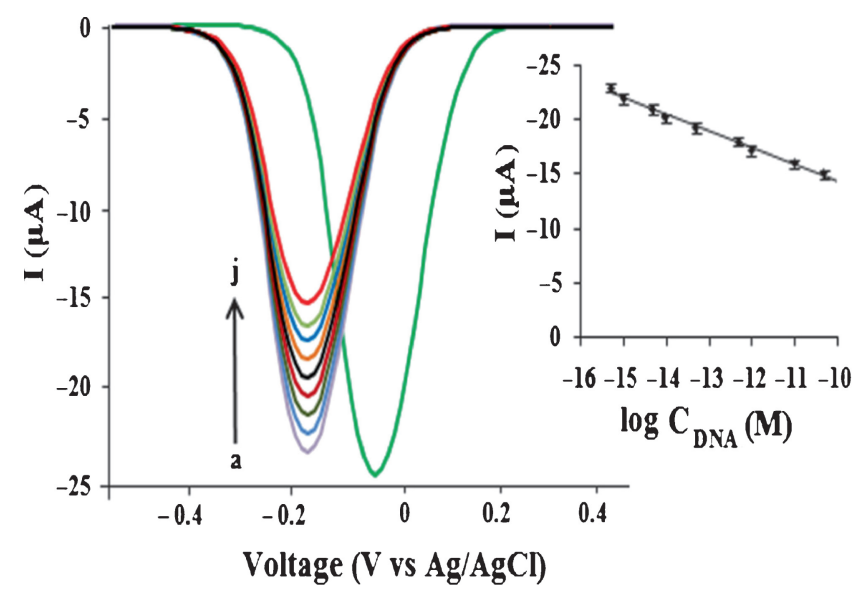

Figure 8. DPV signals of $5.0 \mathrm{mM}\left[\mathrm{Fe}(\mathrm{CN})_{6}\right]^{3-}$ in $0.1 \mathrm{M}$ PBS (pH 7.0) and 0.1 M KCl at ssDNA/AuNPs/G/SPE surface, before (a) and after hybridization with cDNA at different concentrations: $5.0 \times 10^{-16} \mathrm{M}$ (b), $1.0 \times 10^{-15} \mathrm{M}(\mathrm{c})$, $5.0 \times 10^{-15} \mathrm{M}(\mathrm{d}), 1.0 \times 10^{-14} \mathrm{M}(\mathrm{e}), 5.0 \times 10^{-14} \mathrm{M}(\mathrm{f})$, $5.0 \times 10^{-13} \mathrm{M}(\mathrm{g}), 1.0 \times 10^{-12} \mathrm{M}(\mathrm{h}), 1.0 \times 10^{-11} \mathrm{M}(\mathrm{i})$ and $5.0 \times 10^{-11} \mathrm{M}(\mathrm{j})$. Inset: Calibration curve for $\mathrm{I}_{\mathrm{pc}} \mathrm{vs}$. $\log$ $\mathrm{C}_{\mathrm{DNA}}$. Error bars are estimated as the standard deviation from triple measurements $(n=3)$. of the biosensor with different concentrations of complementary target DNA. As can be seen, the signal decreased gradually with increase in the target DNA concentration. The average cathodic peak current $\left(\mathrm{I}_{\mathrm{pc}}\right)$ showed an excellent linear correlation with the logarithmic value of the concentrations of target DNA (log $\mathrm{C}_{\mathrm{DNA}}$ ) in the range of $5 \times 10^{-16}$ to $5 \times 10^{-11} \mathrm{M}$ (Figure 8 ). The regression equation was $\mathrm{I}_{\mathrm{pc}}(\mu \mathrm{A})=1.513 \log \mathrm{C}_{\mathrm{DNA}}$ (M) -0.321 with a correlation coefficient of 0.9985 . The detection limit $\left(3 \mathrm{~S}_{\mathrm{b}} / \mathrm{m}\right.$, where $\mathrm{S}_{\mathrm{b}}$ is the standard deviation of the blank solution, and $\mathrm{m}$ is sensitivity) was calculated as $3.64 \times 10^{-16} \mathrm{M}$ for target DNA.

The analytical performance of the biosensor is compared with previously reported similar works (Table 1). The proposed biosensor showed a better detection limit than the reported results in the literature, with comparable detection range for the complementary target DNA.

\subsection{The stability and reproducibility of the DNA biosensor}

To evaluate the stability of the proposed biosensor, continuous cyclic voltammograms of ssDNA/AuNPs/ $\mathrm{G} / \mathrm{SPE}$ were recorded in $0.1 \mathrm{M} \mathrm{KCl}$ containing $5.0 \mathrm{mM}$ $\left[\mathrm{Fe}(\mathrm{CN})_{6}\right]^{3-/ 4-}$. After $200 \mathrm{CV}$ cycles, the response of the DNA sensor retained about $92 \%$ of its initial value (data not shown), showing excellent stability of the proposed biosensor.

To investigate the reproducibility of the biosensor, six DNA sensors, made in parallel, were used to detect $1.0 \times 10^{-14} \mathrm{M}$ of complementary target DNA sequence. The relative standard deviation (RSD) was $1.9 \%$, indicating a satisfactory reproducibility of the fabricated DNA biosensor.

\section{Conclusions}

A rapid hybridization detection of P53 gene sequences, one of the most popular genes in cancer research, by an effective disposable electrochemical DNA sensor is reported. The constructed biosensor was used to detect the hybridization reaction due to the greatly enhanced electrochemical response of the $\left[\mathrm{Fe}(\mathrm{CN})_{6}\right]^{3-}$

Table 1. Comparison of linear ranges and detection limits for the different electrochemical DNA sensors.

\begin{tabular}{|c|c|c|c|c|}
\hline Electrodes & Analytical technique & Linear range $(\mathrm{M})$ & LOD (M) & Reference \\
\hline $\mathrm{Ph}-\mathrm{NH}_{2} / \mathrm{GO} / \mathrm{GCE}$ & EIS & $1.0 \times 10^{-12}-1.0 \times 10^{-7}$ & $1.1 \times 10^{-13}$ & 42 \\
\hline $\mathrm{WS}_{2}-\mathrm{Gr} / \mathrm{GCE}$ & DPV & $1.0 \times 10^{-14}-5.0 \times 10^{-10}$ & $2.3 \times 10^{-15}$ & 43 \\
\hline $\mathrm{AuNPs} / \mathrm{rGO} / \mathrm{GCE}$ & DPV & $1.0 \times 10^{-13}-1.0 \times 10^{-8}$ & $3.5 \times 10^{-14}$ & 44 \\
\hline Graphene-COOH/GCE & DPV & $5.0 \times 10^{-7}-2.0 \times 10^{-4}$ & $5.0 \times 10^{-8}$ & 45 \\
\hline AuNRs-GO/GCE & DPV & $1.0 \times 10^{-14}-1.0 \times 10^{-9}$ & $3.5 \times 10^{-15}$ & 46 \\
\hline ITO Graphene-Silica-gold & & $1.0 \times 10^{-14}-1.0 \times 10^{-10}$ & $10 \times 10^{-15}$ & 47 \\
\hline AuNPs/G/SPE & DPV & $5.0 \times 10^{-16}-5.0 \times 10^{-11}$ & $3.64 \times 10^{-16}$ & This work \\
\hline
\end{tabular}


ion on this new bioplatform. The good performance and advantages of the proposed biosensor, such as, fast response, simplicity, high sensitivity, good selectivity, excellent stability and reproducibility suggest that this approach could have wide applicability for genetic target analysis in clinical, biomedical and bioanalytical research in the future. In addition, the chosen strategy leads to decrease in time of DNA hybridization detection compared with other electrochemical DNA biosensors that are based on graphene modified electrodes.

\section{References}

1. Guo Y, Chen J H and Chen G N 2013 Sens. Actuators, $B 184113$

2. Kim D, Kerman K, Saito M, Sathuluri R R, Endo T, Yamamura S, Kwon Y and Tamiya E 2007 Anal. Chem. 791855

3. Patolsky F, Lichtenstein A and Willner I $2000 \mathrm{~J}$. Am. Chem. Soc. 122418

4. Zhao X J, Dytioco R T and Tan W H 2003 J. Am. Chem. Soc. 12511474

5. He S J, Liu K K, Su S, Yan J, Mao X H, Wang D F, He Y L, Li J, Song S P and Fan C H 2012 Anal. Chem. 84 4622

6. Silva M M S, Cavalcanti I T, Barroso M F, Sales M G F and Dutra R F 2010 J. Chem. Sci. 122911

7. Lao R J, Song S P Wu, H P Wang L H, Zhang Z Z, He L and Fan C H 2005 Anal. Chem. 776475

8. Erdem A and Ozsoz M 2001 Anal. Chim. Acta 437107

9. Hejazi M S, Raoof J B, Ojani R, Golabi S M and Hamidi-asl E 2010 Bioelectrochemistry 78141

10. Mousavi-Sani S Z, Raoof J B, Ojani R and Hamidi-Asl E 2013 J. Chin. Chem. Soc. 60650

11. Jin Y, Yao X, Liu Q and Li J 2007 Biosens. Bioelectron. 221126

12. Zhang J, Song S P, Wang L H, Pan D and Fan C H 2007 Nature 22888

13. Wang J, Kawde A N and Musameh M 2003 Analyst 128 912

14. Novoselov K S, Geim A K, Morozov S V, Jiang D, Zhang Y, Dubonos S V, Grigorieva I V and Firsov A A 2004 Science 306666

15. Huang X, Yin Z Y, Wu S X, Qi X Y, He Q Y, Zhang Q C, Yan Q Y, Boey F and Zhang H 2011 Small 7 1876

16. Yang S, Li G, Hu M and Qu L 2014 J. Chem. Sci. 126 1021

17. Jeena S E and Selvaraju T 2016 J. Chem. Sci. 128357

18. Vivekchand S R C, Rout C S, Subrahmanyam K S, Govindaraj A and Rao C N R 2008 J. Chem. Sci. 1209

19. Yin Z, Wu S, Zhou X, Huang X, Zhang Q, Boey F and Zhang H 2010 Small 6307
20. Sun X M, Liu Z, Welsher K, Robinson J T, Goodwin A, Zaric S and Dai H J 2008 Nano Res. 1203

21. Liu Z, Robinson J T, Sun X M and Dai H J 2008 J. Am. Chem. Soc. 13010876

22. Zhu L M, Luo L Q and Wang Z X 2012 Biosens. Bioelectron. 35507

23. Gao L N, Yue W B, Tao S S and Fan L Z 2013 Langmuir 29957

24. Xiao Y, Patolsky F, Katz E, Hainfeld J F and Willner I 2003 Science 2991877

25. Yola M L, Eren T and Atar N 2014 Electrochim. Acta 12538

26. Peng H P, Hua Y, Liu P, Deng Y N, Wang P, Chen W, Liu A L, Chen Y Z and Lin X H 2015 Sens. Actuators, B 207269

27. Read A P and Strachan T 1999 In Human Molecular Genetics 2nd ed. (New York: Wiley) Ch. 18

28. Raoof J B, Ojani R, Golabi S M, Hamidi-Asl E and Hejazi M S 2011 Sens. Actuators, B 157195

29. Hamidi-Asl E, Raoof J B, Naghizadeh N, Sharifi S and Hejazi M S 2015 J. Chem. Sci. 1271607

30. Laschi S, Palchetti I, Marrazza G and Mascini M 2006 J. Electroanal. Chem. $\mathbf{5 9 3} 211$

31. Hummers W S and Offernan R E 1958 J. Am. Chem. Soc. 801339

32. Lei C X, Gong F C, Shen G L and Yu R Q 2003 Sens. Actuators, B 96582

33. Pournaghi-Azar M H, Hejazi M S and Alipour E 2006 Anal. Chim. Acta $\mathbf{5 7 0} 144$

34. Pournaghi-Azar M H, Hejazi M S and Alipour E 2007 Electroanalysis 19466

35. Chen Q, Zhang L and Chen G 2012 Anal. Chem. 84171

36. Wang S, Yu D, Dai L, Chang D W and Baek J B 2011 ACS Nano 56202

37. Brown K R, Walter D G and Natan M 2000 J. Chem. Mater. 12306

38. Yang T, Guan Q, Guo X H, Meng L, Du M and Jiao K 2013 Anal. Chem. 851358

39. Yang L J, Li Y B and Erf G F 2004 Anal. Chem. 761107

40. Wang Z J, Zhang J, Chen P, Zhou X Z, Yang Y, Wu S X, Niu L, Han Y, Wang L H, Chen P, Boey F, Zhang Q, Liedberg B and Zhang H 2011 Biosens. Bioelectron. 26 3881

41. Wang X, Zhi L and Mullen K 2008 Nano Lett. 8323

42. Hu Y W, Li F H, Han D X, Wu T S, Zhang Q X, Niu L and Bao Y 2012 Anal. Chim. Acta 75382

43. Huang K J, Liu Y J, Wang H B, Gan T, Liu Y M and Wang L L 2014 Sens. Actuators, B 191828

44. Zhang Y and Jiang W 2012 Electrochim. Acta 71239

45. Huang J, Niu D J, Sun J Y, Han C H, Wu Z W, Li Y L and Xiong X Q 2011 Colloids Surf., B 82543

46. Han X W, Fang X, Shi A, Wang J and Zhang Y Z 2013 Anal. Biochem. 443117

47. Du Y, Guo S, Dong S and Wang E 2011 Biomaterials 328584 